New Zealand Journal of Industrial Relations, 20(1): 35-48

\title{
Trade Unions in Japan: The Consequences of Enterprise Unionism
}

\author{
Ronald L. Miller and Matthew Matsukichi Amano*
}

What passes for a labour movement in Japan is a loose coalition of autonomous, companyspecific unions. These enterprise unions evolved to protect and enhance the interests of a particular group of workers, the regular employees of large corporations. Enterprise unions have shown little or no interest in organising and representing the large majority of Japanese workers, including the rapidly growing female labour force. The characteristics of enterprise unionism that contributed so importantly to the success of "corporate Japan" also contribute to the substantial decline in union density. The restructuring of Japan's economic and political systems required an assessment of the continuing viability of enterprise unionism.

\section{Introduction}

A nation's industrial relations system reflects a multitude of shaping forces: some the conscious choices of decision makers, others the deeply ingrained traits of society. Although the institutions of Japan's industrial relations system largely came into existence after the end of the Second World War, prominent characteristics of employer-union relationships reflect the values of an ancient society.

In less than 50 years, industrial relations in Japan have evolved from violent disruptions to participative management and from a focus on class struggle to the furtherance of corporate well-being. We examine the labour movement that emerged from this transition. The structure and focus of unions have contributed to the pre-eminence of many Japanese corporations and, at the same time, to the declining status of the labour movement.

\section{Structure of the Japanese labour movement}

Enterprise unionism. Since the early 1950s, enterprise unions (Kigyonai Kumiai) have evolved and dominated the Japanese labour movement. Japanese enterprise unions are not administrative units of larger labour organisations - each is an autonomous entity and represents the employees of a specific company. Where a union is established as the collective bargaining representative there is typically only one union per company, regardless of the company's size or diversity of its work force. If a company has multiple 
facilities, each facility includes a sub-unit of that enterprise union. Wages, hours, and other basic working conditions are negotiated centrally and applied throughout the company. In such situations, the headquarters of the multi-unit enterprise union typically are located at or near corporate headquarters. Unions are financed through membership dues; the average union member pays about 4,435 Yen (1.8 percent of salary) per month.

As of 1991, the Japan Institute of Labour recorded 71,685 labour organisations. ${ }^{1}$ Of these, more than 94 percent were classified as company-specific, enterprise unions; the remainder are a few craft unions, multi-company unions, and numerous confederations of enterprise unions. In 1991, 12.4 million workers (or 24.5 percent of the nation's labour force) were members of Japanese unions. While the number of union members has remained about the same since the 1970s, there has been a significant decline in the percentage of union membership since the $1950 \mathrm{~s}$. The reasons for the declining union density are examined later. Evidently, the nature of enterprise unionism provides employment stability for certain workers; however, it also limits labour movement growth.

Industry-wide unionism. In order to coordinate information exchanges and bargaining strategies, enterprise unions have created industry-wide coalitions or confederations called industrial unions (Kigyo-betsu Kumiai) to refer to these loosely-knit organisations. These organisations should not be confused with industrial unions in North America and Western Europe (e.g., United Automobile Workers in the US) which represent very diverse skill levels within an industry and among workers in related industries.

In Japan, the autonomous enterprise unions that voluntarily join together in industry-wide confederations parallel co-operative activities among the industry's employers. However, the first loyalty of the enterprise union is to the economic welfare of its company and second to industry-wide interests. If the companies within an industry are highly competitive, the enterprise unions are limited in the degree that they will co-operate with each other. However, because Japanese companies understand the domestic and foreign advantages of managed competition, bargaining (more appropriately labelled information exchange) between union confederations and employer associations is becoming an increasingly important aspect of the Japanese industrial relations system. ${ }^{2}$

The electrical products and equipment industry provides an example of this system. One enterprise union represents about 92,000 employees of the Matsushita group of companies (Matsushita, Panasonic, National, etc.). This enterprise union is a leading member of a large industrial union confederation, the Electrical Industry Unions Confederation; and its member unions represent over 700,000 workers. Similarly, the companies in the industry have formed a loosely-knit employers association. Although each enterprise union and

1 For comprehensive English language data on the Japanese work force and industrial relations, see Japanese Working Life Profile: 1992-1993, (Tokyo: Japan Institute of Labour, 1992); and LabourManagement Relations in Japan: 1992, (Tokyo, Japan Ministry of Labour, 1992).

2 The theme of adaptation and cooperation to deal with technological changes and market competition is extensively developed in Yasuo Kuwahara, Industrial Relations Systems in Japan: A New Interpretation, (Tokyo: Japan Institute of Labour, 1989). 
company carries out its own negotiations, the union confederation and employers association meet regularly for joint consultations. Beyond information exchange, the goal is to reach agreement on guidelines for the decentralized negotiations. Over the years, enterprise unions and employers have worked to accommodate both co-operation and confrontation in collective bargaining, just as companies have accommodated co-operation and competition in the market place. In addition to issues concerning the terms of employment, union confederations and employer associations are beginning to give increasing attention to public policy issues, such as parental leave, shortening the standard work week, and pension systems.

Union confederations are financed by payments from member enterprise unions. Although there is variation among the confederations, on average 10 percent of the dues paid to an enterprise union by its worker members support confederation membership. The limited funding of union confederations results from a low cost-benefit assessment of confederation services, and an historic reluctance on the part of enterprise unions to support financially multi-union organisations at the industry or national levels. Because the leadership of a union confederation is drawn from its enterprise unions, and enterprise union officials retain important career ties with the companies, union confederations are often dominated by the corporate interests of a few large enterprise unions.

National-level unionism. In addition to the formation of loosely-knit, industry-wide confederations, Japanese enterprise unions have, over the years, created numerous national federations which are analogous, in limited ways, to the AFL-CIO in America. Since 1946, there have been 16 such federations in Japan; they have varied greatly in size and duration. Currently, three national-level union federations exist: the Japanese Trade Union Confederation (Nihon Rodo Kumiai Sorengokai (RENGO)), with 7.6 million members; the Conference of Trade Unions of Japan (Zenkoku Rodokumiai Renraku Kyogikai (ZENROKYO)), with 3 million members; and the National Federation of Trade Unions (Zenkoku Rodokumiai Sorengo (ZENROREN)), with .8 million members. There are also independent enterprise unions representing over 3.6 million workers who have not joined any of these national organisations.

The functions of the federations are, for the most part, limited to facilitating policy coordination among member unions and carrying out various national political activities. Attempts by the federations (most recently by RENGO in 1992) to implement national guidelines for wage negotiations at the enterprise union-company level were not effective.

The evolution of the national level federations in many ways reflects the growing dominance of private sector unions over public sector unions. ${ }^{3}$ The leading unions in the first major union federation, the General Council of Trade Unions of Japan (Nihon Rodokumiai Sohyogikai (SOHYO)), formed in 1950, primarily represented workers in government agencies, education, and government enterprises (telecommunications, railroads, public utilities, etc). These government-based unions held strong socialist and communist

3 For an insightful examination of the development of the Japanese labour movement after the Second World War, see Andrew Gordon, "Japanese Labor Relations During the Twentieth Century", Journal of Labor Research, 11 (Summer 1990): 239-52. 
ideological orientations. With the development of company-focused enterprise unions during the 1950s and 1960s, tension between the private and public unions mounted. In 1964, a major federation of private enterprise unions, the Japan Confederation of Labour (Zen Nippon Rodo Sodomei (DOMEI)), came into existence. Confrontations between SOHYO and DOMEI compounded the factional rivalries, which had historically fragmented the Japanese labour movement. DOMEI's establishment also paralleled the spread of prosperity in Japan, the emergence of economically powerful corporations, and the development of a middle-class mentality among many industrial workers, all of which promoted the dominance of private unions.

The threats to economic prosperity from the oil shocks of the 1970 s reinforced the commitment of enterprise unions to "protect the company", to implement co-operative industrial relations practices, and to support government policies that maintain economic stability. Subsequently, through a series of mergers among federations that were dominated by private enterprise unions, DOMEI evolved and became RENGO in 1987 . Between 1987 and 1989 , additional private sector unions and moderate public sector unions from SOHYO joined RENGO, thereby creating the largest federation of enterprise unions in Japanese history. Meanwhile, the remnants of SOHYO split into two federations, the communistdominated ZENROREN and the radical, socialist-dominated ZENROKYO. With the establishment of RENGO, the business-oriented, politically centrist enterprise unions now personify the Japanese labour movement. One might even say that the labour movement has become part of "Corporate Japan".

Similar to other federations in the past, RENGO operates with a modest budget. About one percent of worker membership dues is allocated by enterprise unions to the national federation. The company-focused, enterprise unions show little inclination to enhance the federation's financial ability to expand its staff and activities. For example, although one of the stated objectives of RENGO is to "organise the unorganised," there is no incentive for an enterprise union to expand its membership beyond its company boundaries. Therefore, enterprise unions are reluctant to financially support RENGO's organising objectives. To date, the enterprise unions have been willing to support only those activities which directly benefit them.

Another constraint on RENGO is the changing values and interests among Japanese workers. For example, the majority of union members, and workers in general, no longer respond to calls to support the class struggle against capitalism. Quite the contrary; most workers, union members or not, identify with political programs that enhance the economic welfare of their employers.

RENGO is having some preliminary success in establishing political alliances between organised labour and employers for pragmatic programs that address such issues as health care reform, housing, and income security for an aging population. However, workers still appear unwilling to support even a politically moderate labour movement. During the elections of 1989 and 1992, elements within RENGO attempted, with little success, to create a new social democratic party. The shambles of the political left in Japan attests to this shift in worker orientation. However, with the unravelling of the Liberal Democratic political monopoly and the emergence of alternative centrist parties, organised labour may find increasing opportunities to establish effective political alliances. 


\section{Enterprise unionism}

Membership. An enterprise union is usually a mixture of regular, white-collar (typically university and college graduates) and regular, blue-collar (typically middle school and high school graduates) employees who are usually called "shain." The word "shain" may literally be translated as "company staff," and signifies the long-term employment commitment, both by the employees and by management. Shain is also associated with the relationship between enterprise union and employer. It implies unity within a community of people who share common interests and destiny. Because of this relationship, regular employees are recruited, screened, selected, and employed through careful and timeconsuming processes.

The sharp distinctions often drawn between management and labour in North American and Western European industrial relations systems are not common in Japanese companies due, in part, to the concept of shain. As a result, over the years, differences in the terms and conditions of employment between regular, white-collar and regular, blue-collar employees have been muted. ${ }^{4}$.

Many employees, who are union members during their early years with a company, climb the corporate ladder into managerial and executive positions. Active union membership does not taint a worker's career. On the contrary, service as an elected union officer is especially important. Such service provides opportunities to demonstrate leadership and consensus building capabilities, as well as commitment to the welfare of members and the company.

Employment conditions. Regular company employees, blue-collar and white-collar, have special employment entitlements including life-time employment, seniority-based compensation, substantial annual bonuses, salary status, and lucrative overtime provisions. Additionally, large corporations typically seek to preserve employment of their regular work force by adjusting to technological changes and product market fluctuations through continuous training and transfers to positions within the parent company and its subsidiaries. As a result of these policies and practices, the income differences between white-collar and blue-collar regular employees have narrowed and there is a high degree of equality in employment security.

The special status and security enjoyed by regular employees comes at the expense of the company's provisional employees. Employers and the enterprise unions use the provisional work force as a buffer to protect the regular employees in adjusting to technological changes and market fluctuations. ${ }^{5}$ Regardless of their length of employment, these

4 The thesis that the most distinctive and important feature of the Japanese industrial relations system is the "white collarisation" of manual workers in large enterprises is developed in Kazuo Koike, Understanding Industrial Relations in Modern Japan, (New York: Macmillan, 1988).

5 For a comprehensive analysis of the economic status of non-regular workers, especially women who comprise the bulk of the provisional employees, see Norma Chalmers, Industrial Relations in Japan: The Peripheral Workforce, (New York: Routledge, 1989). 
provisional employees are commonly referred to as part-time or temporary employees. In most companies, the provisional employees are not union members, nor are they represented by the enterprise union. Provisional employees do not have the income and employment security of regular employees. Annual bonuses, employment benefits, and retirement provisions are considerably less lucrative, if they are provided at all. These differences in employment security and compensation affect women most adversely. While women comprise 35 percent of regular employees, they account for 68 percent of provisional employees.

Blue-collar work force. Technological changes and subcontracting of production operations are reducing the ranks of blue-collar employees in most enterprise unions. Union representation is concentrated in large companies and, in the dominant manufacturing sector, those firms employ significantly fewer blue-collar workers. As a result, the Japanese labour movement is increasingly comprised of university educated, white-collar workers.

Technological innovations in labour-intensive production processes (e.g., assembling, sorting, packing) have been rapid and pervasive. At large companies, many of the manufacturing processes once handled by blue-collar workers are now highly automated. To meet their changing personnel requirements, companies are up-grading the skills of some regular, blue-collar employees to work as set-up specialists and robotics technicians.

The reductions in blue-collar employment resulting from technological innovations are compounded by mounting domestic and international product market competition. Large Japanese corporations are cutting production costs by subcontracting unskilled and semiskilled operations to domestic subsidiaries, affiliated suppliers, and foreign companies. As a result of these structural changes, blue-collar employment in Japan's manufacturing sector is increasingly concentrated in the numerous small firms that serve the large corporations. Only a small proportion of these firms are unionised.

As technology and competition take their toll among blue-collar workers, the shain relationship has been stretched thin. A regular blue-collar employee who is transferred to a domestic subsidiary or affiliated supplier remains employed, but often at lower pay and reduced benefits.

With the reduction in blue-collar employment, enterprise unions have attempted to counter membership losses by expanding their representation among technical, administrative, and professional employees in their companies. It can be argued that, as a consequence of this shift in the occupational mix of union membership, the Japanese labour movement has become less confrontational, more supportive of participative management, and more politically moderate.

Union officers' shadow careers. An important feature of enterprise unionism is the special, personal relationships maintained between union officials and their companies. Union officers typically receive an unpaid leave of absence from their employers and are paid by the union. It is also common for union officers to continue "shadow careers" with their companies. Therefore, if the union officer terminates the leave of absence and returns to paid employment with the company, he will resume his career as though it has not been 
interrupted. This means the union official is advanced in salary and steps along the promotional ladder, consistent with the advancement of his peers. Moreover, a union leader may spend the bulk of his working life within the labour movement, while, as an employee on a leave of absence, he retains pension rights with his company. Enterprise union leaders and regular company employees retire at the same age.

Compulsory union membership. At the same time that shadow career paths link union officials to their enterprise, collective bargaining agreements commonly provide for union shops which assure enterprise unions compulsory membership and maximum income from dues. Since an enterprise union typically limits its representation to regular company employees, the union does not have to recruit new members. New hires are required to join the union and pay dues for as long as they are employees of the company. Almost all enterprise unions have a dues check-off system. If a company expands into new ventures, the enterprise union automatically represents the regular employees of the new ventures. Most Japanese unions have no experience with, or interest in, organising workers of other companies for union membership and representation.

\section{Mutuality of interests}

Shared destiny. Enterprise unionism has evolved into an institutionalised mechanism through which the employer and the regular employees focus on the economic welfare of the company. ${ }^{6}$ Japanese employers and their enterprise unions perceive and jointly act upon common interests, as if they have a "shared destiny" (UNMEI KYODOTAI) to a degree not found in adversarial industrial relations systems. In Japan, to promote mutual well-being, major decisions are made only after consultations between management and the enterprise union. The parties have created multiple channels for communication, information exchange, negotiations, and participative decision making. For all practical purposes, the enterprise union has become a component of the company's organization, an integral part of the managerial structure.

As co-managers within the enterprise, union leaders co-operate more with their corporate colleagues than with their counterparts in other unions. The union leaders realize that the long-term existence and growth of their companies is a precondition for ultimately increasing the income and employment security of the union's members. Increased domestic and international competition have reinforced the mutuality of interests between an enterprise union and its company. Most union leaders accept the premise that the enterprise union must not be a barrier to the effective operation of the company. ${ }^{7}$ The challenge for a union is to balance fair and equitable treatment of its members with

6 Changes in the industrial relations system resulting from the 1970 s oil shocks are examined in Michio Nitta, "Structural Changes and Enterprise-Based Unionism in Japan", Searching for a New System in Industrial Relations, (Tokyo: Japan Institute of Labour, 1989).

7 The benefits of enterprise unionism, "decentralisation and specialisation" are advocated in Katsuro Sakoh, "Economic Implications of Enterprise Unionism", Journal of Labor Research 11 (Summer 1990): 257-67. 
economic viability for the company. Accordingly, union leaders do not resist technological innovations and continuous improvement: rather, training and work assignment policies that foster employment security are encouraged.

In contrast to the experiences of managers in adversarial industrial relations systems, Japanese enterprise unionism makes the task of running a company far less confrontational. It is assumed that, if the parties have established trust and information reliability, a broad range of shared interests can be identified, accommodated, and acted on. ${ }^{8}$ A vice-president for industrial relations of a large corporation characterised the collective bargaining process as "confrontation surrounded by co-operation."

Exclusions and limitations. Shared destiny does not necessarily include the welfare of provisional (non-regular) employees. As noted earlier, the employment security of the company's regular employees is protected by the use of provisional employees, who have been a shock absorber during recessions.

The application of shared destiny is very company specific. As enterprise unions increasingly focus on the economic welfare of their respective employers, intensified competition among companies has impeded union co-operation. These divergent economic interests compound the problems of a labour movement that has a long history of ideological fragmentation and little solidarity.

The leaders of ZENROREN, the communist dominated federation of mostly public sector unions, are among the most severe critics of enterprise unionism. Their sharpest criticism is levelled against its adverse impact on worker solidarity, including the protection of regular employees at the expense of provisional employees. They charge that, because most enterprise union officials have shadow careers with their companies, the unions do not function well as a check on company management. The critics contend that what passes for co-operation is, in reality, company domination and that enterprise unions are not independent advocates. They also claim that the enterprise unions are indifferent to the welfare of the bulk of Japanese workers, who are not represented by any union.

\section{Union membership and density}

Decreasing membership. The Japanese labour movement is facing a crisis. Over the past 20 years, while the national work force has increased by almost 50 percent, total union membership has remained largely unchanged. Table 1 shows that union density has declined from a peak of 46.2 percent of the work force in 1950 , to 24.5 percent in 1991 . The total number of union members has not significantly changed since the early $1970 \mathrm{~s}$.

8 The theory that the success of the Japanese industrial relations system is based on investment in technical skills, trust relationships, and information reliability is developed in Masanori Hashimoto, The Japanese Labor Market in a Comparative Perspective with the United States, (Kalamazoo, Mich.: W.E. Upjohn Institute, 1990). 
Table 1: Union Membership and Density in Japan, 1959-1991

\begin{tabular}{||c|c|c||}
\hline Year & Union Membership & Density \\
\hline 1950 & $5,773,908$ & 24.2 \\
\hline 1955 & $6,285,878$ & 35.6 \\
\hline 1960 & $7,661,568$ & 32.2 \\
\hline 1965 & $10,146,872$ & 34.8 \\
\hline 1970 & $11,604,770$ & 35.4 \\
\hline 1975 & $12,590,400$ & 34.4 \\
\hline 1980 & $12,369,262$ & 30.8 \\
\hline 1985 & $12,417,527$ & 28.9 \\
\hline 1990 & $12,264,509$ & 25.2 \\
\hline 1991 & $12,396,592$ & 24.5 \\
\hline
\end{tabular}

Source: Japanese Working Life Profile: 1992-1993. Japan Institute of Labour, Tokyo, 1992.

Density Variation. Union density rates vary greatly among Japan's major industries; see Table 2. The historic core of the labour movement, public service employees, has the highest rate of union membership at 72 percent. However, government's share of total employment has been declining due to privatisation (railroads and communication) and down-sizing. As of 1991, government employed about four percent of the nation's work force.

Unions in the manufacturing sector now represent about a third of all organised labour in Japan. Among manufacturing workers, 29.9 percent are union members. Union representation in this sector is highly concentrated in larger corporations. Enterprise unions also represent employees in the recently privatised railroad and communication industries; the high rate of union membership, 46.1 percent, is a carry-over from the period of government ownership.

The image of Japan as a manufacturing powerhouse belies the fact that half of all workers are employed in the service sector. The failure of the labour movement to keep pace with labour market changes is most evident in the low density rates of the service, 14 percent, and retail/wholesale, 8.8 percent, industries. 
Table 2: Unionisation by Industry in Japan, 1991

\begin{tabular}{||l|c|c||}
\hline Industry & $\begin{array}{c}\text { Number of Union } \\
\text { Members }\end{array}$ & $\begin{array}{c}\text { Percentage of } \\
\text { Industry Workers } \\
\text { Unionised }\end{array}$ \\
\hline All industries & $12,397,000$ & 24.5 \\
Manufacturing & $4,097,000$ & 29.9 \\
Service and Health Care & $1,694,000$ & 14.1 \\
Transportation and & $1,682,000$ & 46.1 \\
Communication & $1,430,000$ & 72.6 \\
Public Service & $1,167,000$ & 47.6 \\
Finance and Insurance & 955,000 & 8.8 \\
Retail/Wholesale/Hospitality & 849,000 & 17.3 \\
Construction & 219,000 & 60.9 \\
Utilities & 53,000 & 11.2 \\
Agriculture & 21,000 & 42.2 \\
Mining & 230,000 & - \\
Other Industries & & \\
\hline
\end{tabular}

Source: Labour-Management Relations in Japan: 1992. Japan Ministry of Labour, Tokyo.

\section{Analysis of declining union density}

Manufacturing sector. Although total employment in the manufacturing sector remained stable between 1970 and 1990, the sector's share of total domestic employment declined from 35 percent to 27 percent. During these two decades, the industrial mix within the manufacturing sector changed substantially. Strongly unionised and labour-intensive segments, such as ship building and steel making, dwindled. Other major segments of the sector, such as automobile manufacturing and electronics, underwent massive technological changes, shifts in skill and educational composition of job classifications, and reductions in employment, especially among blue-collar workers.

Also during this period, there has been a shift of blue-collar employment from large corporations to the numerous, small firms that are affiliated with these corporate groups. In part, this shift reflects the efforts of the larger companies to provide continued employment for former regular employees. Furthermore, and more important, the shift is

9 Corporate groups have become a dominant feature of the manufacturing sector. A corporate group consists of a core enterprise (such as Nissan) that is linked to primary subcontractors (such as Calsonic) who in turn are linked to numerous, small subcontractors and affiliated supplier. The members of a group co-ordinate operating policies and employee compensation under the "leadership" of the core enterprise. The intent is to establish long-term relationships and adjustment practices that reduce threats from destabilising forces (inside and outside the group). 
part of a strategy of the large companies to reduce their costs by relocating production to lower-cost (and lower-paying) subcontractors. Therefore, although total employment in manufacturing has been stable since the early 1970 s, blue-collar employment in this sector has shifted from predominately unionised, large companies to predominately unorganised, small firms. Unions in the manufacturing sector are trying to compensate for membership losses by expanding their representation among white-collar employees and by representing all regular employees within new ventures undertaken by their companies.

Service sector. In contrast to the manufacturing sector, during the period from 1970 to 1990, the service sector increased its share of total domestic employment from 39 percent to 50 percent. The Japanese labour movement has a mixed record of representing workers in this sector. Enterprise unions are well established among financial and insurance companies, with union density at 47.6 percent. However, among the other segments of the service sector (retail, wholesale, hospitality, health care, etc.), density rates are below 15 percent.

There are two main reasons for low density rates. First, large numbers of part-time, intermittent, second-income, and female workers are employed by these companies. Historically, service sector workers have not shown strong interest in union representation. Many factors, ranging from societal attitudes to exemptions from income tax, have discouraged union representation among these workers.

Second, few unions actively organise in the service sector. Outside the financial and insurance segment of the sector, most companies do not have enough employees to financially support individual enterprise unions. As a consequence, one of the unique labour organisations in Japan, the Textile, Garment, Chemical, Distributive and Allied Industry Workers' Union (ZENSENDOMEI), re-structured itself to represent retail and wholesale workers across company lines. Formerly, ZENSENDOMEI was a traditional enterprise union in the textile industry. Rather than decline with the domestic textile industry, ZENSENDOMEI shifted its representational activities to the expanding service sector. Now, its organisational structure and aggressive organising activities are more like a typical American industrial union, such as the United Food and Commercial Workers Union. Unless more enterprise unions re-structure themselves to represent workers across company lines, union density will remain low.

Company size. There is a high correlation between company size and unionisation. Companies with 1,000 or more employees are 60 percent unionised, while companies with less than 100 employees are 2 percent unionised. Japan is a nation of small scale firms; more than 80 percent of the labour force are employed at companies with 300 or fewer employees. Given the trend for large Japanese employers to down-size through subcontracting and technological innovations, employment growth will continue to be confined to small- and medium-size firms.

The company-specific nature of enterprise unionism requires a sufficient number of duespaying employees to support financially the union's operations. Union members in the larger companies are able to generate such operating revenue. Therefore, if the Japanese labour movement maintains its company-specific, enterprise union orientation, density rates will continue to decline. 
Company dominated associations. Friendship associations (KONSHIKAI) established by many nonunion companies also contribute to the decline in union density. Japanese labour legislation sanctions the creation, by employers, of in-house organisations for informal consultation, participative management, and problem solving. Although employer dominated, friendship associations provide important work group identification, opportunities for the development of group commitment, and a means to focus on the economic welfare of the company. Most small-to-medium size companies do not have sufficient market strength to be wage setters. Therefore, they adhere to wage and benefit patterns established among the peer subcontractors or follow industry trends. Workers in a small company understand that an enterprise union would not alter this reality. For many workers, a friendship association is an adequate, dues-free alternative to enterprise union representation.

Friendship associations also provide employers with an effective means of resisting union representation without having to take overtly anti-union positions. In Japan, blatant antiunionism on the part of management, while legal, is generally considered inappropriate public conduct.

Company-specific union. A number of factors explain declining union density in Japan; the most important is the very nature of enterprise unionism. The primary functions of an enterprise union are to enhance employment security and attain equitable compensation for regular employees by fostering the economic welfare of the company. Shadow careers and vested interests of union leaders reinforee the company-specific orientation of enterprise unionism.

Organising workers outside the company is not a task generally performed by enterprise unions. Company compulsory union membership provisions in collective bargaining agreements assure maximum membership within the company. Unless a union can justify spending dues-generated revenue to organise workers outside the company, the union's membership is not likely to support such activities. In the service sector, ZENSENDOMEI has established such justification through union-contract-based job security and multiemployer wage negotiations. The uniqueness of ZENSENDOMEI among Japanese unions comes from its industry-wide organising activities, multi-employer membership base, and large staff of professional organisers.

Blurred focus. The decline of the Japanese labour movement involves more than density rates. Unions, once among the leaders in the class struggle, now have little to offer the largely middle class and prosperous labour force. Early in the post-Second World War period, worker concerns for wages, benefits, and job security were easily identified. The labour movement, led by the militant public sector unions, presented itself as the standard bearer of progress and the vanguard of modernisation. However, with the growth of enterprise unionism during the $1950 \mathrm{~s}$ and $1960 \mathrm{~s}$, the focus of attention among private sector workers shifted from the class struggle to the economic welfare of individual companies. The company, not the enterprise union or the labour movement, became primary to the workers' economic well being. 
The oil shocks of the 1970 s intensified the linkage of company welfare and national economic policies. As corporate executives and ministry officials devised adaptive strategies, it was evident that the labour movement was not a significant player in the management of the nation's economy.

During the $1980 \mathrm{~s}$, in the context of sustained prosperity and improving standards of living, most enterprise unions accepted collaborative roles in the management of their enterprises. In doing so, workers find it difficult to differentiate between the roles of corporate management and union leadership.

Now, organised labour does not have issues that give clear identity or justify strong worker support. For the bulk of Japanese workers, the labour movement is increasingly irrelevant in their economic, political, and social lives. Ideological squabbles among the socialist factions within the labour movement have little relevance to the concerns of most workers. Organised labour exercises minimal political influence, although individual enterprise unions do support the political objectives of their companies.

A widening generation gap confronts the labour movement. Among younger Japanese men and women, there is a trend to seek and express individual identity, rather than to conform with group norms. Younger workers, in particular, react negatively to the traditional trappings of unionism including mass meetings, group chants, marching under the red flag of class struggle, etc. If younger workers identify with and are loyal to any organization, it is to their employer, and even that loyalty is weakening. Younger women especially find little with which to identify in a labour movement dominated by men and largely indifferent to the economic interest of provisional employees.

\section{Concluding comments}

Japanese enterprise unions evolved to protect and enhance the interests of a particular group of workers, the regular employees of large corporations. These unions have fulfilled this function very well. A web of personal and institutional relationships harmonises the economic interests of workers and employers, focuses on mutual survival, and reflects the acceptance of a shared destiny. Depending upon one's disposition, the relationships could be characterised as co-management through consensus decision making, or as manipulation and domination by corporate management. However viewed, the results include no restrictions on technological innovation and worker utilisation, high quality and efficiency norms, employment security, and rising real wages.

Among regular employees, trust in this system is being tested during the recession of the 1990s. To date, the pain associated with down-sizing has been felt mostly by those employees not represented by the enterprise unions - middle management (early retirements and forced transfers) and provisional employees (employment terminations). Additionally, cost cutting pressures have been transmitted down through the layers of affiliated, nonunion subcontractors. 
The function of enterprise unionism is narrowly drawn so that the large majority of Japanese workers are not intended beneficiaries. Within a company, regular employees are often protected at the expense of provisional employees. With few exceptions, enterprise unions do not seek to extend representation beyond the company's boundaries. Cooperation among enterprise unions at the industry and national levels is limited and highly dependent on the identification of self-interest outcomes. Therefore, what passes for a labour movement in Japan is a loose coalition of autonomous unions.

Membership density is an imperfect measure of labour movement health. Nevertheless, as in Japan, where the decline has been long-term and substantial, it suggests important institutional limitations. Although the enterprise union model has been very successful in serving the interests of regular employees in Japan's large corporations, this type of union has limited application in an economy composed primarily of small firms. To be economically viable, the enterprise union model requires that each employer have a large work force. As a result, the numerous small firms of the manufacturing sector are unorganised.

By way of contrast, in the expanding service sector (composed primarily of small and medium size firms), a different union model is evolving. ZENSENDOMEI (a former enterprise union) has abandoned its company-specific orientation in order to establish a membership among numerous retail and wholesale employers. This evolving industrial-type union could represent the future of a renewed Japanese labour movement. It remains to be seen if other enterprise unions are willing and able to make the transition. 